\title{
Geomorphological analysis and prioritization of sub-watersheds using Snyder's synthetic unit hydrograph method
}

\author{
Nivedita Singh $\cdot$ K. K. Singh
}

Received: 14 March 2014/ Accepted: 16 October 2014/Published online: 23 November 2014

(C) The Author(s) 2014. This article is published with open access at Springerlink.com

\begin{abstract}
The present study makes an attempt to prioritize sub-watersheds based on Snyder's synthetic unit hydrograph method. Snyder's method of synthetic unit hydrograph calculates peak discharge and lag time of the unit hydrograph for each sub-watersheds. Compound values of ranking are calculated from assigned rankings to parameters, viz. peak discharge and lag time. Depending on the range of the compound values sub-watersheds are classified as high, medium and low soil-erosive subwatersheds. The priorities obtained from Snyder's synthetic unit hydrograph method are compared with the methods of morphometric analysis and land use/land cover analysis. On comparison of priorities for Dangri River watershed, Panchkula District, Haryana (India), among the three methods it was found that the sub-watershed (SW1) has the same priority. Among all the three methods, Snyder's synthetic unit hydrograph is a better method, as it is easier to use and less data intensive.
\end{abstract}

Keywords Watershed · Priority - Morphometry · Synthetic unit hydrograph $\cdot$ Land use $\cdot$ Land cover

\section{Introduction}

The sustainable management of fresh water is a major challenge of the twenty-first century. To conserve the existing status of water resources and cope with the increasing demand of water of the rapidly growing

N. Singh $(\varangle) \cdot$ K. K. Singh

Civil Engineering Department, NIT Kurukshetra, Haryana, India

e-mail: niveditasinghrana@gmail.com

K. K. Singh

e-mail: k_k_singh_2000@yahoo.com population of the country, as well as the problems that are likely to arise in future, a holistic, well-planned long-term strategy is needed for sustainable water resources management. For proper planning and management of natural resources, it is necessary to understand the hydrological behavior of watershed. However, soil degradation in the watershed of the river system generates several problems. The severity is more pronounced in remote areas. Soil degradation ultimately affects river water quantity and quality as well as induces many associated problems such as flooding, submergence of land and aquatic life disturbance. So, management of soil degradation is very necessary to keep the river system healthy. Geomorphologic studies play an important role in predicting the hydrological behavior of watersheds. The morphometric analysis of a drainage basin and its stream system can be better achieved through measurement of linear and shape aspects of drainage network and contributing ground slopes. Morphometric analysis could be used for prioritization of sub-watersheds by computing linear and shape parameters (Biswas et al. 1999). Several studies in the recent past have been done on prioritization of watersheds (Aher et al. 2013; Allen et al. 2001; Arun et al. 2005; Bera and Bandyopadhyay 2013; Javed et al. 2009; Katiyar et al. 2006; Khan et al. 2001; Martin and Saha 2007; NookaRatnam et al. 2005; Rashid and Sahu 2014; Reddy et al. 2004; Shrimali et al. 2001; Singh et al. 2014; Suresh et al. 2004; Thakkar and Dhiman 2007; Tripathi et al. 2013; Vittala et al. 2008). For assessment of erosion, several empirical models based on the geomorphological parameter were developed in the past for quantifying the sediment yield (Chowdary et al. 2013; Jose and Das 1982; Misra et al. 1984). Chaudhary and Sharma (1998) performed erosion hazard assessment and prioritization based on morphometric parameters. Several empirical methods such as sediment yield index method proposed 


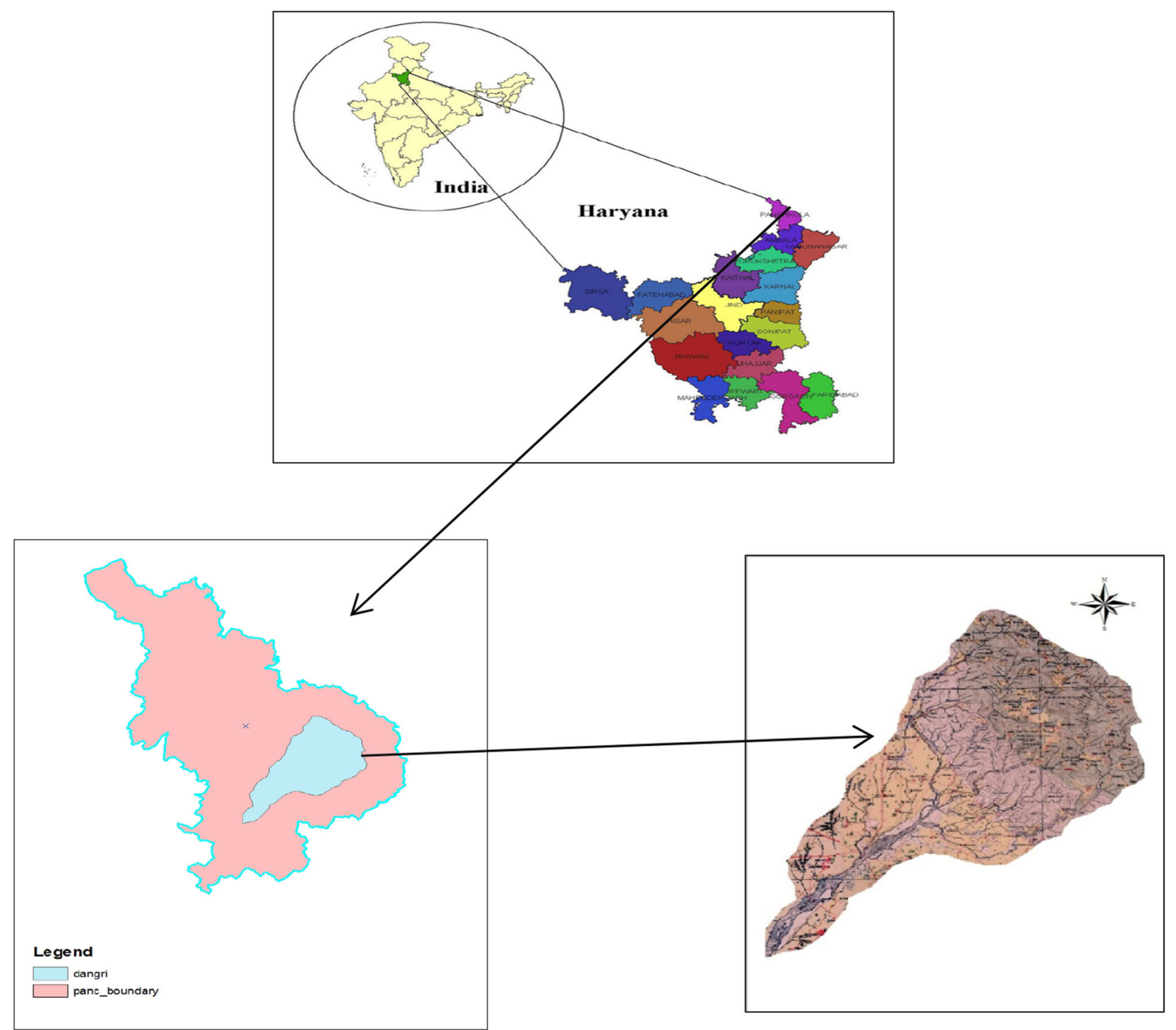

Fig. 1 Location map of study area

by Lu et al. (2003) and Universal Soil Loss Equation (USLE) given by Wischmeier and Smith (1978) are extensively used in the prioritization of watersheds. Garde and Kothari (1987) developed an empirical relationship involving catchment area, catchment slope, drainage density vegetation cover factor and annual precipitation for average annual sediment yield estimation using the data of 50 catchments located in the plain region of India.

Pandey et al. (2007) divided the Karso watershed of Hazariabagh, Jharkhand State, India, into $200 \times 200 \mathrm{~m}$ grid cells and average annual sediment yields were estimated for each cell of the watershed to identity the critically prone areas of watershed. Recent studies (Pandey et al. 2007; Yoshino and Ishioka 2005; Sharma et al. 2001; Khan et al. 2001; Sidhu et al. 1998) revealed that remote sensing (RS) and geographic information system (GIS) techniques are of great use in characterization and prioritization of watershed areas using land use/land cover methods (Kulkarni et al. 2014; Waikar and Nilawar 2014; Warrier and Manjula 2014). Conventional method to drive morphological parameters is expensive, time consuming and more prone to error. Use of land use/land cover method is often severely limited by the lack of adequate data, particularly in developing nations.

\section{Study area}

Dangri River watershed is situated in Raipur Rani block of Panchkula District in Haryana (India), covers an area of 


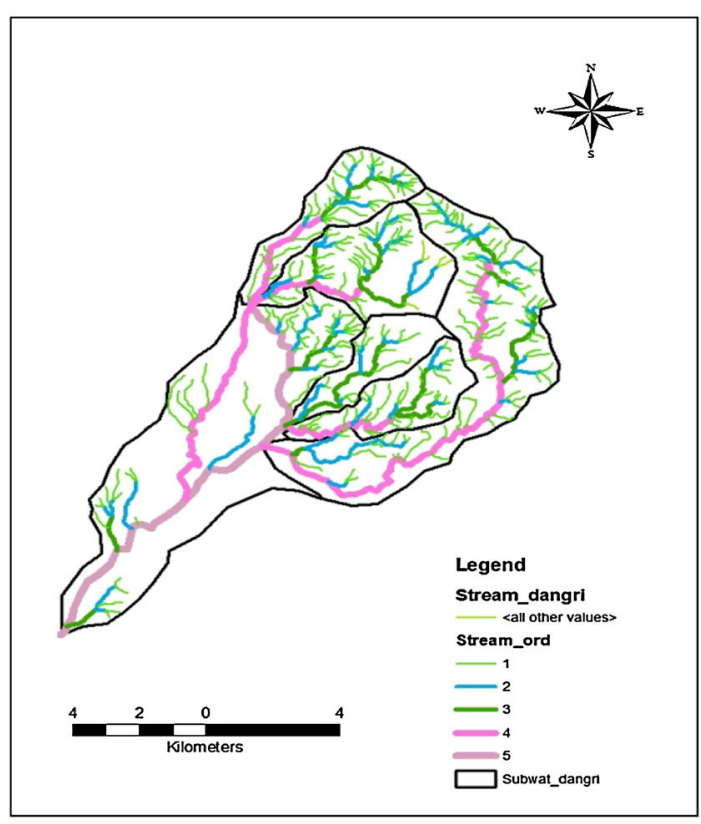

Fig. 2 Stream network and sub-watershed of study area

$114.12 \mathrm{~km}^{2}$ and is bound between $76^{\circ} 96$ to $77^{\circ} 65$ longitude and $30^{\circ} 55$ to $30^{\circ} 7$ latitude. The maximum and minimum elevations encountered in the watershed are 1206 and $463 \mathrm{~m}$ above mean sea level. The River Dangri rises in the lower Shivalik at the foothills of the Himalayas and joins River Ghaggar. River Ghaggar disappears in the desert of Rajasthan after a run of about $280 \mathrm{~km}$. The main hydrogeomorphic units found in the study area are alluvial plain, flood plain, denudational hill, piedmont zone, intermountain valley and structural hill. Excellent to good groundwater prospect zones cover about $40 \%$ area of the district, whereas the rest of the area is constituted by denudational and structural hills that have moderate to poor and nil prospects. Figure 1 shows the location map of the study area.

\section{Data used}

Survey of India toposheets bearing numbers $53 \mathrm{~F} / 2$ and $53 \mathrm{~B} / 14$ on $1: 50,000$ scale were used for preparation of the base map. Standard geocoded false color composite of the Indian remote sensing satellite (IRS-1C) LISS III (PathRow 096-055) having spatial resolution $23.5 \mathrm{~m}$ was procured from the National Remote Sensing Centre (NRSC), Hyderabad. Besides, secondary information/data were collected from Javed et al. (2009), Thakkar and Dhiman (2007) and Biswas et al. (1999). Limited ground truth verification was carried out in some areas of the watershed.

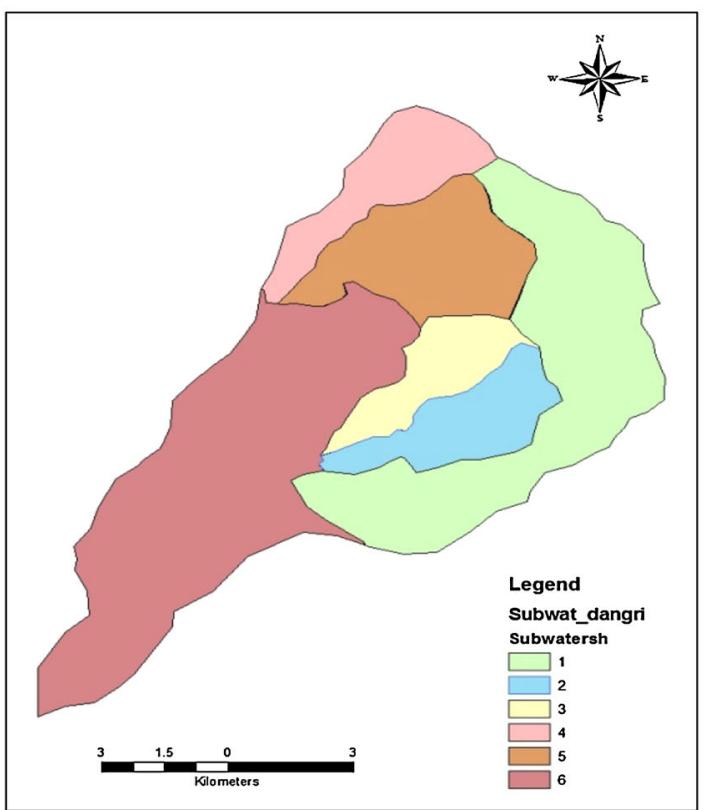

\section{Materials and methods}

Open series maps of toposheets on 1:50,000 scale of the study area were acquired from Survey of India, scanned and mosaicked for the purpose of geo-referencing and delineation. Digitization work was carried out for the entire watershed using GIS software (Arc GIS 9.2). The Dangri watershed was further subdivided into six subwatersheds on the basis of drainage flow direction, slope, relief and elevation. The sub-watersheds are designated as SW1-SW6, the smallest being SW3 covering $7.2 \mathrm{~km}^{2}$ area, whereas the largest covers $42.76 \mathrm{~km}^{2}$ area. The order was given to each stream by following Strahler (1964) stream order technique, i.e., two first-order streams join to make a second order. Two second-order streams join to make a third order and so on. The attributes were assigned to create the digital database for drainage layer of the river basin. The map showing the drainage pattern in the study area (Fig. 2) was prepared. The Dangri watershed has been divided into six sub-watersheds and details of each sub-watershed are given in Table 1. The study area shows dendritic to subdendritic drainage pattern and parallel to subparallel pattern was also found in some areas.

Snyder's method of synthetic unit hydrograph

Synthetic unit hydrographs are derived for ungauged watershed by computing various coefficients based on 
Table 1 Details of sub-watersheds in the study area

\begin{tabular}{|c|c|c|c|c|c|c|c|c|}
\hline \multirow[t]{2}{*}{ Sub-watershed } & \multirow[t]{2}{*}{ Area $\left(m^{2}\right)$} & \multirow[t]{2}{*}{ Perimeter (m) } & \multicolumn{2}{|c|}{ Elevation (m) } & \multirow[t]{2}{*}{ Total relief (m) } & \multirow[t]{2}{*}{ No. of streams } & \multirow{2}{*}{$\begin{array}{l}\text { Max. length of } \\
\text { watershed (m) }\end{array}$} & \multirow{2}{*}{$\begin{array}{l}\text { Total streams } \\
\text { length }(\mathrm{m})\end{array}$} \\
\hline & & & Max. & Min. & & & & \\
\hline SW1 & 31457544 & 36812 & 1206 & 372 & 834 & 116 & 20583 & 81262 \\
\hline SW2 & 8806420 & 15736 & 789 & 502 & 287 & 40 & 8008 & 27127 \\
\hline SW3 & 7240342 & 14679 & 770 & 403 & 367 & 19 & 6442 & 16116 \\
\hline SW4 & 9399409.07 & 17007 & 1202 & 517 & 685 & 54 & 8081 & 32772 \\
\hline SW5 & 14452809.01 & 17880 & 711 & 517 & 194 & 60 & 8005 & 41285 \\
\hline SW6 & 42764201.01 & 38282 & 463 & 320 & 143 & 66 & 16040 & 71874 \\
\hline
\end{tabular}

Table 2 Basic Equation of Synders Method

\begin{tabular}{|c|c|c|c|}
\hline $\begin{array}{l}\text { S. } \\
\text { no. }\end{array}$ & Name of equation & Equation & Used abbreviation \\
\hline 1. & & $t_{p}=C_{\mathrm{t}(L \cdot L \mathrm{ca})}^{0.3}$ & \multirow{4}{*}{$\begin{array}{l}\mathrm{C}_{\mathrm{t}}(0.3-6.5) \text { and } \mathrm{C}_{\mathrm{p}} \\
(0.56-0.69) \text { are empirical } \\
\text { constants depending on } \\
\text { the watershed } \\
\text { characteristics after that } \\
\text { the parameter for deriving } \\
\text { the synthetic unit } \\
\text { hydrograph, such as } t_{\mathrm{p}}, Q_{\mathrm{p}} \\
\text { are also calculated } \\
\text { (Suresh 2012) }\end{array}$} \\
\hline 2. & Peak flow rate & $Q_{p}=\frac{2.78 A C_{\mathrm{p}}}{t_{\mathrm{p}}}$ & \\
\hline 3. & $\begin{array}{l}\text { Width of unit } \\
\text { hydrograph at } 50 \% \\
\text { of peak discharge }\end{array}$ & $W_{50}=\frac{5.87}{\mathrm{q}^{1.08}}$ & \\
\hline 4 & Peak discharge & $q=\left(Q_{\mathrm{p}} \mid A\right)$ & \\
\hline
\end{tabular}

the physical features of the watershed. The synthetic unit hydrographs are developed on the basis of known physical characteristics of gauged watershed which is identical hydrologically and meteorologically to the watershed whose rainfall and runoff data are not available. Snyder (1938) developed a set of empirical relations on the basis of a large number of hydrographs resulting from several watersheds ranging from 25 to $2500 \mathrm{~km}^{2}$ in size.

To derive the synthetic unit hydrograph for the watershed, the data such as area (A), longest length of stream flow path (L) and length along the main stream from the gauging station to a point opposite the center of gravity of the watershed $\left(L_{\mathrm{ca}}\right)$ are determined. The empirical relations of lag time and peak flow rate are given in Table 2.

Method of morphometric analysis

Various morphometric parameters such as linear and shape aspects of the drainage network, viz. stream order $\left(N_{\mathrm{u}}\right)$, bifurcation ratio $\left(R_{\mathrm{b}}\right)$, stream length $\left(L_{\mathrm{u}}\right)$ and areal aspects of the drainage basin, including drainage density $\left(D_{\mathrm{d}}\right)$, stream frequency $\left(D_{\mathrm{f}}\right)$, texture ratio $(T)$, elongation ratio $\left(R_{\mathrm{e}}\right)$, circulatory ratio $\left(R_{\mathrm{c}}\right)$ and form factor ratio $\left(R_{\mathrm{f}}\right)$ of the basin were computed as given in Table 3 .
Table 3 Formulae of morphometric parameters

S. Morphometric Formula/definition

no. parameters

1. Bifurcation ratio $R_{\mathrm{b}}=N_{\mathrm{u}} / N_{\mathrm{u}+1}$

$\left(R_{\mathrm{b}}\right) \quad$ Where, $N_{\mathrm{u}}=$ number of stream segments present in the given order, $N_{\mathrm{u}+1}=$ number of segments of the next higher order

2. Drainage density $D_{\mathrm{d}}=\Sigma L_{\mathrm{u}} / A_{\mathrm{u}}$

$\left(D_{\mathrm{d}}\right) \quad$ Where, $L_{\mathrm{u}}=$ total stream length of all orders $(\mathrm{km}), A=$ area of the basin $\left(\mathrm{km}^{2}\right)$

3. Texture ratio $(T) \quad T=\Sigma N_{\mathrm{u}} / P$

$P=$ perimeter $(\mathrm{km})$

4. Stream frequency $D_{\mathrm{f}}=\Sigma N_{\mathrm{u}} / A$

$\left(D_{\mathrm{f}}\right)$

5. Form factor $\left(R_{\mathrm{f}}\right) \quad R_{\mathrm{f}}=\mathrm{A}_{\mathrm{u}} / L_{\mathrm{b}}^{2}$

Where, $\mathrm{A}_{\mathrm{u}}=$ area of the basin $\left(\mathrm{km}^{2}\right), L_{\mathrm{b}}=$ maximum basin length $(\mathrm{km})$

6. Circularity ratio $\mathrm{R}_{\mathrm{c}}=4 \pi \mathrm{A} / P^{2}$

$\left(R_{\mathrm{c}}\right) \quad$ Where, $\mathrm{A}_{\mathrm{u}}=$ basin area $\left(\mathrm{km}^{2}\right), P=$ perimeter of the basin $(\mathrm{km})$

7. Elongation ratio $R_{\mathrm{e}}=\sqrt{ } \mathrm{A} / \pi / L_{\mathrm{b}}$ $\left(R_{\mathrm{e}}\right)$

8. Compactness coefficient $(\mathrm{Cc})$

Where, $A_{\mathrm{u}}=$ area of the basin $\left(\mathrm{km}^{2}\right), L_{\mathrm{b}}=$ maximum basin length $(\mathrm{km})$

$C c=\frac{P_{b}}{2 \sqrt{\pi A}}$

Where, $\mathrm{Pb}=$ perimeter of thr basin, $2 \sqrt{\pi A}=$ circumference of circular area

Method of land use/land cover

The LAND-SAT ETM map images for the study area were downloaded from http://www.glcf.umiacs.umd.edu. The images were used to prepare land use/land cover map. Base map of the study area was overlaid on satellite data to delineate various categories of land use/land cover through standard visual image interpretation method based on photo recognition elements such as tone, texture, size, shape, pattern, association and field knowledge. Various land use/land categories were delineated on the basis of 
Fig. 3 Land use/land cover map of sub-watersheds
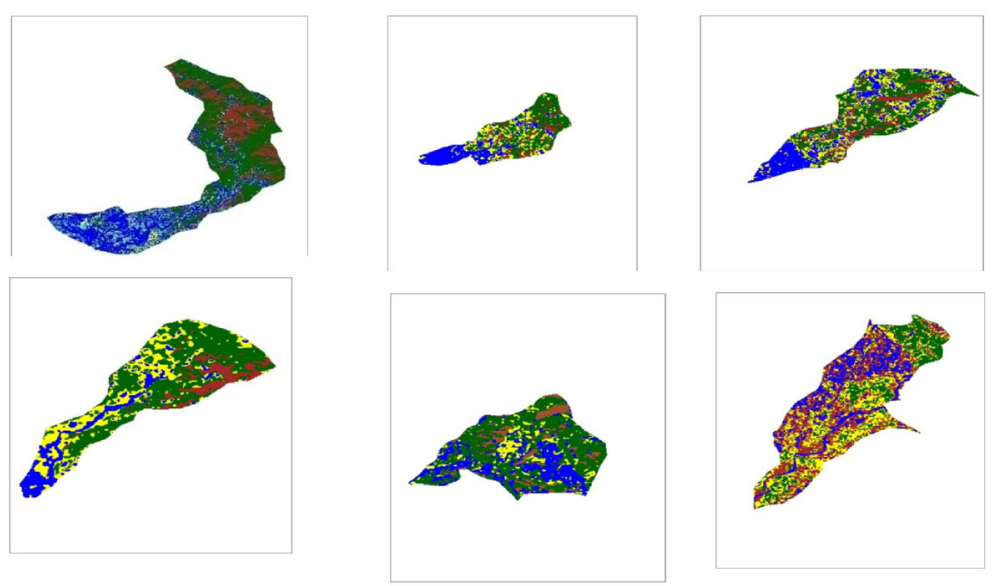

Legen

Class_name

waterbod open

Fores

Agri spectral signature and terrain characteristics which were supplemented by limited ground truth verification.

Land use/land cover mapping was carried out at subwatershed level using IRS LISSIII data. Ground features were identified on the basis of reflectance recorded by the sensor and converted into digital values which are classified by supervised classification method. In Dangri watershed, four land use/land cover classes were identified, i.e., waterbody, agriculture, forest and open land using unsupervised classification. Figure 3 shows the land use/land cover map.

\section{Prioritization}

Then prioritization was done on the basis of synthetic unit hydrograph parameters, morphometric parameters and land use land cover analysis. After assigning ranking based on every single parameter, the rated values for each watershed were averaged to arrive at an average value, $C_{\mathrm{r}}$. Based on the average value of these parameters, the watershed having the least value of $C_{\mathrm{r}}$ is assigned the highest priority denoted by 1 , the watershed with the next highest value of composite rating is assigned a priority denoted by number 2 and so on. The sub-watershed that got the highest value of $C_{\mathrm{r}}$ is assigned the last priority number. In synthetic hydrograph more value of lag time $\left(t_{\mathrm{p}}\right)$ and width of hydrograph $\left(W_{50}\right)$ can be considered as negative means more prone to erosion and more value of peak flow means less prone to erosion. The morphometric parameters, i.e., drainage density, stream frequency, bifurcation ratio, texture ratio, length of overland flow, form factor, circularity ratio, elongation ratio, basin shape and compactness coefficient are also termed as erosion risk assessment parameters and have been used for prioritizing sub-watersheds (Biswas et al. 1999). Hence, ranking of priority/rank based on highest value in case of linear parameters and lowest value in case of shape parameters. For prioritization of sub-watersheds, in case
Table 4 Prioritization of sub-watersheds based on synthetic hydrograph of study area

\begin{tabular}{lrllllll}
\hline Sub-watershed & $L(\mathrm{~km})$ & $L_{\mathrm{ca}}(\mathrm{km})$ & \multicolumn{1}{l}{$t_{\mathrm{p}}$} & $Q_{\mathrm{p}}$ & $W_{50}$ & $C_{\mathrm{r}}$ & Priority \\
\hline SW1 & 18.76 & 23.59 & 9.33 & 5.15 & 41.63 & 2.3 & $\mathbf{H}$ \\
SW2 & 7.75 & 23.59 & 7.15 & 1.88 & 31.18 & 2.6 & $\mathbf{H}$ \\
SW3 & 5.74 & 23.59 & 6.54 & 1.69 & 28.30 & 4.3 & $\mathbf{L}$ \\
SW4 & 7.55 & 23.59 & 7.10 & 2.02 & 30.87 & 4.3 & $\mathbf{L}$ \\
SW5 & 7.59 & 23.59 & 7.11 & 3.10 & 31.03 & 4.0 & $\mathbf{M}$ \\
SW6 & 16.04 & 23.59 & 8.90 & 7.34 & 39.53 & 3.3 & $\mathbf{M}$ \\
\hline
\end{tabular}

of linear parameters, the highest value was given a rating of 1 , the next higher value was given a rating of 2 and so on. Whereas for the shape parameters, the lowest value was given a rating of 1 , the next lower value was given rating of 2 and so on. In land use/land cover analysis, high priority has been assigned to the sub-watershed having a higher percentage of open land or lower percentage of cultivated land and forest cover, whereas low priority has been given to the watershed which has higher percentage of cultivated land and forest cover or lower percentage of open land.

\section{Result and discussion}

This section of the paper presents the results obtained during the study along with discussion wherever required.

Snyder's synthetic unit hydrograph

The values of lag time of sub-watershed are presented in Table 4. The SW1 has maximum value of $t_{\mathrm{p}}=9.33$, while SW3 has a minimum value of $t_{\mathrm{p}}=0.30$. The $W_{50}$ values of sub-watersheds are presented in Table 3. The SW1 has a maximum value of $W_{50}=41.63$, while SW3 has a minimum value of $W_{50}=28.30$. 
$*$ Lag time $\left(t_{\mathrm{p}}\right)$, and width of watersheds $\left(W_{50}\right)$

Morphometric method

This technique has been used for varied characteristics of drainage basin, which include erosion surfaces, nature of erosion and formation of slope.

\section{Linear parameters}

Linear parameters consist of bifurcation ratio, drainage density, stream frequency, drainage texture and length of overland flow.

The SW1 has maximum $\left(R_{\mathrm{b}}\right)=4.49$, while SW5 has a minimum $R_{\mathrm{b}}\left(R_{\mathrm{b}}=2.10\right)$. The value of $R_{\mathrm{b}}$ for sub-watersheds shows that influences of geological structure on the drainage network are negligible. The sub-watershed 4 has a maximum value $\left(D_{\mathrm{d}}=3.48\right)$, while sub-watershed 6 has minimum $D_{\mathrm{d}}\left(D_{\mathrm{d}}=1.68\right)$. Low value of drainage density $\left(D_{\mathrm{d}}\right)$ for the sixth watershed indicates that it has high resistance and impermeable subsoil material with dense vegetative cover and low relief. Sub-watershed 4 has a high value of $D_{\mathrm{d}}$, indicating a well-developed network and torrential runoff resulting in intense flood. The sub-watershed
4 has maximum $\left(D_{\mathrm{f}}=5.74\right)$, while sub-watershed 6 has minimum $D_{\mathrm{f}}\left(D_{\mathrm{f}}=0.15\right)$. The values of drainage frequency of sub-watershed area exhibits positive correlation with drainage density values of the area, indicating the increase in the drain population with respect to drainage density. Texture ratio $(T)$ is an important factor in drainage morphometric analysis which depends on the underlying lithology, infiltration capacity and relief aspects of the terrain. The values of the texture ratio of 1 sub-watershed are presented in Table 4 . The sub-watershed has maximum $(T=2.49)$, while sub-watershed 2 has minimum $T(T=0.88)$ values. The values of the linear parameters for the six sub-watersheds are presented in Table 5.

*Bifurcation ratio $\left(R_{\mathrm{b}}\right)$, drainage density $\left(D_{\mathrm{d}}\right)$, stream frequency $\left(D_{\mathrm{f}}\right)$, texture ratio $(T)$.

\section{Shape parameters}

Shape parameters consist of form factor, circulatory ratio, elongation ratio and compactness coefficient.

The sub-watershed 6 has a maximum value $\left(R_{\mathrm{f}}=1.66\right)$, while sub-watershed 1 has minimum value $\left(R_{\mathrm{f}}=0.07\right)$. A low value of farm factor $\left(R_{\mathrm{f}}\right)$ indicates elongated shape of the sub-watershed. The elongated basin with farm factor

Table 5 Sub-watershed wise computed morphometric parameter of study area

\begin{tabular}{lllllllllll}
\hline Sub-watershed & $R_{\mathrm{b}}$ & $D_{\mathrm{d}}$ & $D_{\mathrm{f}}$ & $T$ & $R_{\mathrm{f}}$ & $R_{\mathrm{c}}$ & $R_{\mathrm{e}}$ & $C_{\mathrm{c}}$ & $C_{\mathrm{r}}$ & Priority \\
\hline SW1 & 4.49 & 2.58 & 3.68 & 2.49 & 0.07 & 0.29 & 0.30 & 1.85 & 2.37 & VH \\
SW2 & 2.38 & 3.08 & 4.54 & 1.97 & 0.13 & 0.44 & 0.41 & 1.49 & 3.00 & $\mathbf{M}$ \\
SW3 & 3.98 & 2.22 & 2.62 & 0.88 & 0.17 & 0.42 & 0.47 & 1.53 & 4.12 & $\mathbf{L}$ \\
SW4 & 2.73 & 3.48 & 5.74 & 2.46 & 0.14 & 0.45 & 0.42 & 1.56 & 3.25 & $\mathbf{H}$ \\
SW5 & 3.41 & 2.85 & 4.15 & 2.46 & 0.22 & 0.40 & 1.69 & 1.32 & 3.37 & M \\
SW6 & 2.10 & 1.68 & 0.15 & 1.27 & 1.66 & 0.29 & 1.45 & 1.65 & 4.62 & $\mathbf{L}$ \\
\hline
\end{tabular}

Table 6 Prioritization of sub-watershed based on land use/ land cover analysis

\begin{tabular}{|c|c|c|c|c|c|c|c|c|}
\hline \multirow{2}{*}{$\frac{\text { S. no. }}{\text { SW1 }}$} & \multicolumn{2}{|c|}{ Cultivated area $\left(\mathrm{m}^{2}\right)$ and $(\%)$} & \multicolumn{2}{|c|}{ Forest area $\left(\mathrm{m}^{2}\right)$ and $(\%)$} & \multicolumn{2}{|c|}{ Open land area $\left(\mathrm{m}^{2}\right)$ and $(\%)$} & \multirow{2}{*}{$\frac{C_{\mathrm{r}}}{2.3}$} & \multirow{2}{*}{$\frac{\text { Priority }}{\mathbf{H}}$} \\
\hline & (1) & & (4) & & (2) & & & \\
\hline & $1,779,208.86$ & 5.70 & $14,467,949.27$ & 46 & $4,706,445.86$ & 14.9 & & \\
\hline \multirow[t]{2}{*}{ SW2 } & (3) & & (3) & & (6) & & 4 & $\mathbf{M}$ \\
\hline & $1,851,831.11$ & 21.1 & $3,515,325.81$ & 39.9 & $895,065.18$ & 10.1 & & \\
\hline \multirow[t]{2}{*}{ SW3 } & (4) & & (2) & & (3) & & 3 & $\mathbf{M}$ \\
\hline & $1,629,124.76$ & 22.5 & $2,672,841.36$ & 36.9 & $1,009,348.66$ & 13.9 & & \\
\hline \multirow[t]{2}{*}{ SW4 } & (5) & & (5) & & (5) & & 5 & $\mathbf{L}$ \\
\hline & $2,333,996.59$ & 24.9 & $4,671,484.74$ & 49.65 & $959,649.43$ & 10.2 & & \\
\hline \multirow[t]{2}{*}{ SW5 } & (2) & & (6) & & (4) & & 4 & $\mathbf{L}$ \\
\hline & $1,473,538.47$ & 10.19 & $7,668,413.77$ & 53.05 & $1,644,607.17$ & 11.4 & & \\
\hline \multirow[t]{2}{*}{ SW6 } & (6) & & (1) & & (1) & & 2.6 & $\mathbf{H}$ \\
\hline & $19,147,527.41$ & 44.8 & $8,303,912.37$ & 19.40 & $7,806,328.135$ & 18.6 & & \\
\hline
\end{tabular}



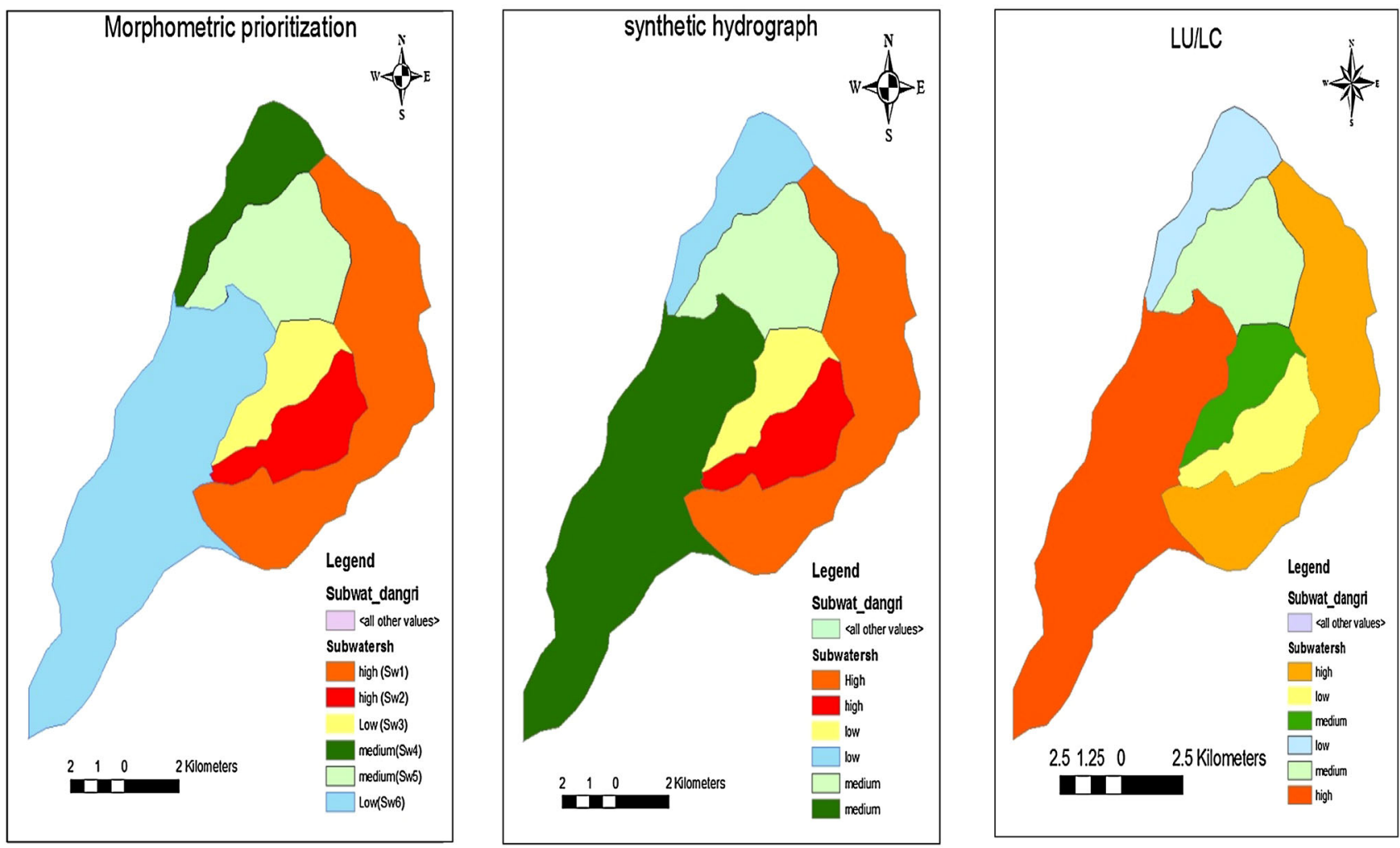

Fig. 4 Prioritization on the basis of morphometric analysis land use/land cover and synthetic hydrograph

Table 7 Comparison of watershed priorities

\begin{tabular}{llll}
\hline $\begin{array}{l}\text { Sub- } \\
\text { watershed }\end{array}$ & $\begin{array}{l}\text { Prioritization } \\
\text { ranking by } \\
\text { synthetic } \\
\text { hydrograph }\end{array}$ & $\begin{array}{l}\text { Prioritization } \\
\text { ranking by } \\
\text { morphometric } \\
\text { analysis }\end{array}$ & $\begin{array}{l}\text { Prioritization } \\
\text { ranking by land } \\
\text { use/land cover }\end{array}$ \\
\hline SW1 & 1 (high) & 1 (high) & 1 (high) \\
SW2 & 2 (high) & 2 (high) & 4 (medium) \\
SW3 & 5 (low) & 5 (low) & 3 (medium) \\
SW4 & 6 (low) & 3 (medium) & 6 (low) \\
SW5 & 4 (medium) & 4 (medium) & 5 (low) \\
SW6 & 3 (medium) & 6 (low) & 2 (high) \\
\hline
\end{tabular}

indicates that the sub-watersheds will have flatter peaks for longer duration. The circulatory ratio $\left(R_{\mathrm{c}}\right)$ is influenced by the length and the frequency of the stream, geological structure, vegetation cover, climatic, relief and slope of the basin. The values of circulatory ratio of all sub-watersheds are presented in the Table 4 . The sub-watershed 5 has a maximum value $\left(R_{\mathrm{c}}=0.45\right)$, while sub-watershed 1 has a minimum value $\left(R_{\mathrm{c}}=0.29\right)$. The sub-watershed 5 has a maximum value of $R_{\mathrm{e}}=1.69$, while sub-watershed 1 has a minimum value of $R \mathrm{e}\left(R_{\mathrm{e}}=0.30\right)$. The elongation ratio value range of sub-watersheds shows that these subwatersheds are elongated in shape. A circular basin is the most susceptible from a drainage point of view, because it will yield the shortest time of concentration before peak flow occurs in the basin (NookaRatnam et al. 2005). Values of compactness constant of five sub-watershed are presented in the Table 4 . The sub-watershed 1 has a maximum value $\left(C_{\mathrm{c}}=1.85\right)$, while sub-watershed 4 has a minimum value $\left(C_{\mathrm{c}}=1.32\right)$. The values of shape parameters for six sub-watersheds are presented in Table 5.

*Form factor $\left(R_{\mathrm{f}}\right.$, circulatory ratio $\left(R_{\mathrm{c}}\right)$, elongation ratio $\left(R_{\mathrm{e}}\right)$, compactness coefficient $\left(C_{\mathrm{c}}\right)$.

\section{Land use/land cover method}

Cultivated land may be defined as land used for farming. The total cultivated area of the water shed is $28,215,227.2$ $\mathrm{Km}^{2}$, i.e., $24.7 \%$. The maximum cultivated area is $\mathrm{SW} 1=44.8 \%$, whereas the minimum cultivated area is $\mathrm{SW} 1=5.70$. The sub-watershed with lower percentage of cultivated land has been given higher priority, whereas subwatershed having higher percentage of cultivated land is assigned lower priority. The total forest area of the watershed is $41,299,927.32 \mathrm{~km}^{2}=36.2 \%$. The maximum forest area is SW5 $=53.05$, whereas minimum forest area is SW6 $=19.40$. The sub-watershed with lower percentage of forest land has been given higher priority, whereas subwatershed having higher percentage of forest land is assigned lower priority. Open land is the land that is 
unused, desolate, barren or ravaged. The total open land of the watershed is $17,021,444.44 \mathrm{~km}^{2}$, i.e., $14.9 \%$. The maximum open land is SW6 $=18.6$, whereas minimum open land is SW2 $=10.1$. The sub-watershed with lower percentage of waste land has been given higher priority, whereas sub-watershed having higher percentage of waste land is assigned lower priority. Values of land use/land cover factors for six sub-watersheds are presented in Table 6.

Prioritization of sub-watershed on the basis of synthetic hydrograph

For prioritization of sub-watershed, viz., lag time, peak flow rate and width of watersheds were considered. As general rule, high priority has been assigned to the subwatershed having higher value of lag time and width of unit hydrograph and lower value of peak flow. The prioritization of sub-watersheds based on synthetic hydrograph is presented in Table 4. The final priority/ranking was given by classifying the highest and lowest range of $C_{\mathrm{r}}$ value into three classes as high (2.3-2.6), medium (3.3-4.0) and low (>4.3). Hence, on the basis of synthetic hydrograph, SW1 and SW2 have high priority, SW6 and SW5 have medium priority and SW3 and SW4 have low priority.

Prioritization of sub-watersheds on the basis of morphometric analysis

The linear parameters such as drainage density, stream frequency, bifurcation ratio and texture ratio have direct proportional relationship with erodibility whereas shape parameters such as elongation ratio, circulatory ratio, form factor and compactness coefficient have inverse relationship with erodibility (NookaRatnam et al. 2005).

The sub-watersheds were then categorized into three classes as high (2.3-3.00), medium (3.25-3.75) and low (4.12-4.62) priority. Hence, on the basis of morphometric parameters, SW1 and SW2 have high priority, SW4 and SW5 have medium priority and SW3 and SW6 have low priority. The prioritization of sub-watersheds based on morphometric analysis is presented in Table 5.

Prioritization of sub-watershed on the basis of land use/ land cover analysis

For prioritization of sub-watershed, viz., cultivated land, forest cover and open land were considered. The prioritization of sub-watershed based on land use/land cover analysis is presented in Table 6 .

SW1 normally shows high priority based on all the three methods, and SW2 shows high-low priority based on two methods, i.e., (morphometric analysis and synthetic hydrograph). However, SW2 from LU/LC showed medium priority and SW3 showed low-high priority from morphometric analysis and synthetic hydrographs, but from LU/LC showed medium priority. SW4 normally shows low-high priority from synthetic unit hydrograph and LU/ LC, but from morphometric analysis shows medium priority. SW5 normally shows medium-low priority from morphometric analysis and synthetic hydrograph, but from LU/LC it shows low priority. SW6 has little and no correlation. SW1 and SW2 watersheds have high priority and have been taken up for soil and water conservation measures. Figure 4 and Table 7 show the comparison of priorities obtained from all the three methods.

\section{Conclusion}

Prioritization is considered to be one of the key factors for rapid development and management of watersheds. SW1 has been found to have high priority, i.e., highly soil eroded watershed which has been estimated from all the three methods. So, it will need early attention of soil and water conservation measures. The present study demonstrates the utility of synthetic hydrograph as one of the useful techniques for prioritization of sub-watersheds, which requires least data and effort as compared to the other two methods, i.e., morphometric analysis and land use/land cover analysis.

Open Access This article is distributed under the terms of the Creative Commons Attribution License which permits any use, distribution, and reproduction in any medium, provided the original author(s) and the source are credited.

\section{References}

Aher PD, Adinarayan J, Gorantiwar SD (2013) Prioritization of watershed using multi criteria evaluation through fuzzy analytical hierarchy process. Agric Eng Int CIGR J 15(1):11-18

Allen CG, Andres C, Sheldon ML (2001) Developing a geomorphic approach for ranking watersheds for rehabilitation, Zuni India reservation, New Mexico. J Geomorphol 37(1\& 2):105-134

Arun PS, Jana R, Nathawat MS (2005) A rule based physiographic characterization of a drought prone watershed applying remote sensing and GIS. J Indian Soc Remote Sens 33(2):189-201

Bera K, Bandyopadhyay J (2013) Prioritization of watershed using morphometric analysis through geoinformatics technology: a case study of Dungra sub watershed, West Bengal, India. Int $\mathbf{J}$ Adv Remote Sens GIS 2(1):1-8

Biswas S, Sudhakar S, Desai VR (1999) Prioritization of subwatersheds based on morphometric analysis of drainage basin, District Midnapore, West-Bengal. J Indian Soc Remote Sens 27(3):155-166

Chaudhary RS, Sharma ED (1998) Erosion hazard assessment and treatment prioritization of Giri river catchment, north western Himalayas. Indian J Soil Conserv 26(1):6-11

Chowdary VM, Chakraborthy D, Jeyaram A, Krishna murthy YVN, Sharma JR, Dadhwal VK (2013) Multi criteria decision making 
approach for watershed prioritization using hierarchy process technique and GIS. J Water Res Manag 27:3555-3571

Garde RJ, Kothari UC (1987) Sediment yield estimation. J Irrig Power (India) 44(3):97-123

Horton RE (1945) Erosional development of stream and their drainage basin: hydrophysical approach to quantitative morphology. Bull Geol Soc Am 56:275-370

Javed A, Khanday MY, Ahmed R (2009) Prioritization of subwatersheds based on morphometric and land use analysis using remote sensing and GIS technique. J Indian Soc Remote Sens 37:261-274

Jose CS, Das DC (1982) Geomorphic prediction models for sediment production rate and intensive prioritiesof watershed in Mayurakshi Watershed. In: Proceedings of the international symposium on hydrologicalaspects of mountainous watershed held at the School of Hydrology. University of Roorkee, vol 1(4\&6): 15-23

Katiyar R, Gara PK, Jain SK (2006) Watershed prioritization and reservoir sedimentation using remote sensing data. Geocarto Int 21(3):55-60

Khan MA, Gupta VP, Moharanam PC (2001) Watershed prioritization using remote sensing and geographical information system: a case study from Guhiya, India. J Arid Environ 49:465-475

Kulkarni UD, Davalbhakt HA, Waikar ML (2014) Geomorphological analysis of tank catchment using geographical information system: a case STUDY. Int J Emerg Technol Adv Eng 4(7):867-872

Lu XX, Ashmore P, Wang J (2003) Sediment yield mapping in a large river basin: the upper Yangtze, China. J Env Model Softw 18:339-353

Martin D, Saha SK (2007) Integrated approach of using remote sensing and GIS to study watershed prioritization and productivity. J Indian Soc Remote Sens 35(1):21-30

Miller VC (1953) A quantitative geomorphic study of drainage basin characteristics in the Clinch Mountain area, Vargina and Tennessee, Project NR 389-042, Tech. Rept. 3, Columbia University, Department of Geology, ONR, Geography Branch, New York

Misra N, Satyanarayana T, Mukherjee RK (1984) Effect of topo elements on the sediment production rate from sub watersheds in upper Damodar valley. J Agric Eng 21(3):65-70

Nag SK (1998) Morphometric analysis using remote sensing techniques in the Chaka sub-basin, Purulia district, West Bengal. J Indian Soc Remote Sens 26(1\&2):69-76

Nautiyal MD (1994) Morphometric analysis of drainage basin using ariel photograph: a case study of Khairkuls basin, district Dehradun, UP. J Indian Soc Remote Sens 2(4):251-261

NookaRatnam K, Srivastava YK, VenkateshwaraRao V, Amminedu E, Murthy KSR (2005) Check dam positioning by prioritization of micro-watersheds using SYI model and morphometric analysis- remote sensing and GIS perspective. J Indian Soc Remote Sens 33(1):25-38

Pandey A, Chowdary VM, Mal BC (2007) Identification of critical erosion prone areas in the small agricultural watershed using USLE, GIS and remote sensing. J Water Resour Manag 21:729-746

Rashid M, Sahu RN (2014) Watershed prioritization on the basis of morphometric parameters: a remote sensing and GIS based approach. Int Res J Sustain Sci Eng 2(1):1-6

Reddy OG, Maji AK, Gajbhiya SK (2004) Drainage morphometry and its influence on landform characteristics in a basaltic terrain, central India- a remote sensing and GIS approach, Internat. J Appl Earth Obs Geoinformatics 6:1-16
Schumn SA (1956) Evaluation of drainage system and slopes in bad lands at Perth Amboy, New Jersy. Bull Geol Soc Am 67:597-646

Sharma JC, Prasad J, Saha SK, Pande LM (2001) Watershed prioritization based on sediment yield index in eastern part of Don valley using RS and GIS. Indian J Soil Conserv 29(1):7-13

Shrimali SS, Aggarwal SP, Shamra JS (2001) Prioritization erosionprone areas in hills using remote sensing and GIS - a case study of the Sukhna Lake catchment Northern India. Int J Appl Earth Obs Geoinformatics 3(1):54-60

Sidhu GS, Das TH, Singh RS, Sharma RK, Ravishankar T (1998) Remote sensing and GIS techniques for prioritization of watershed: a case study in upper Mackkund watershed, Andhra Pradesh. Indian J Soil Conserv 2(3):71-75

Singh N, Tiwari P, Guru PK, Khalkho D (2014) Morphometric analysis for prioritization of watershed using GIS technique. Int J Agric Eng 7(1):69-73

Snyder FF (1938) Synthetic unit hydrographs. Trans Am Geophys Union 19:447-454

Strahler AN (1964) Quantitative analysis geomorphology of drainage basins and channel Networks. In: Chow VT (ed) Handbook of applied hydrology. McGraw Hill Book Company, New York section 4-11

Suresh R (2012) Soil and water conservation engineering. (ISBN: 978-81-8014-186-7)

Suresh M, Sudhakar S, Tiwari KN, Chowdary VM (2004) Prioritization of watersheds using morphometric parameters and assessment of surface water potential using remote sensing. J Indian Soc Remote Sens 32(3):249-259

Thakkar KA, Dhiman SD (2007) Morphometric analysis and prioritization of mini-watersheds in Mohr Watershed, Gujarat, using remote sensing and GIS techniques. J Indian Soc Remote Sens 35(4):313-321

Tripathi S, Soni SK, Maurya AK (2013) Morphometric characterization and prioritization of Sub Watershed of Seoni River in Madhya Pradesh, through remote sensing and GIS technique. Int J Remote Sens Geosci 2(3):46-54

Upendra NO (1998) Morphological analysis of small watershed in the western Ghat region of Kerala. Natl Geogr J India 44(14):190-200

US Army corps of Engineers (1959) Engineering construction flood control, Fort Belvoir, V.A. Engg School

Vittala SS, Govindaiah S, HomeGowda H (2008) Prioritization of sub-watersheds for sustainable development and management of natural resources: an integrated approach using remote sensing, GIS and socio-economic data. J Curr Sci 95(3):345-354

Waikar ML, Nilawar AP (2014) Morphometric analysis of a drainage basin using geographical information system: a case study. Int J Multidiscip Curr Res 2:179-184

Warrier U, Manjula P (2014) Morphometric Analysis of Thuthapuza Sub Basin, Kerala, India. Int Res J Sustain Sci Engineering 2(7): $1-10$

Wischmeier WH, Smith DD (1978) Predicting rainfall erosion losses, USDA, Agricultural Research Service Handbook. pp. 537

Yoshino K, Ishioka Y (2005) Guidelines for soil conservation towards integrated basin management for sustainable development: a new approach based on the assessment of soil loss risk using remote sensing and GIS, Paddy. Water Environ 3:235-247

Zavoianu I (1985) Morphometry of drainage basins development in Water Science, vol 20. Elsevier, Oxford, Amsterdam, New York, pp $1-238$ 